\title{
Diversity of sea cucumber from intertidal area of Pacitan and Bangkalan, East Java, Indonesia
}

\author{
ELSA DIANITA AULIA ${ }^{1}$, FARID KAMAL MUZAKI ${ }^{1, \bullet}$, DIAN SAPTARINII, EDWIN SETIAWAN ${ }^{2}$, \\ DAVIN SETIAMARGA ${ }^{3}$, ISWATUL DIAH LUTVIANTI ${ }^{1}$, SANIAH KUSNATUR ROSYIDAH ${ }^{1}$, \\ NUR ALI MUHAMMAD ${ }^{1}$
}

${ }^{1}$ Marine Ecology and Conservation Research Group, Ecology Laboratory, Department of Biology, Faculty of Science and Data Analytics, Institut Teknologi Sepuluh Nopember. Jl. Raya ITS, Surabaya 60111, East Java, Indonesia. Tel./fax.: +62-813-85438580, `email: rm_faridkm@bio.its.ac.id; faridmuzaki@gmail.com

${ }^{2}$ Zoology and Animal Engineering Laboratory, Department of Biology, Faculty of Science and Data Analytics, Institut Teknologi Sepuluh Nopember. Jl. Raya ITS, Surabaya 60111, East Java, Indonesia

${ }^{3}$ Department of Applied Chemistry and Biochemistry, National Institute of Technology, Wakayama College. Noshima 77, Nada-cho, Gobo City, Wakayama, Japan 644-0023, Japan

Manuscript received: 21 February 2021. Revision accepted: 30 March 2021.

\begin{abstract}
Aulia ED, Muzaki FK, Saptarini D, Setiawan E, Setiamarga D, Lutvianti ID, Rosyidah SK, Muhammad NA. 2021. Diversity of sea cucumber from intertidal area of Pacitan and Bangkalan, East Java, Indonesia. Biodiversitas 22: 2136-2141. Sea cucumbers have an important role in the regeneration and mineralization processes of marine sediments. They are echinoderm, and their existence influences the sustainability of other organisms in different types of marine ecosystems. The objective of the present study was to determine the diversity of sea cucumber at Tawang and Pidakan coasts in Pacitan, and Labuhan coast in Bangkalan with slight differences in habitat characteristics. Sampling was conducted from $1000 \mathrm{~m}^{2}$ marked plots using hand collecting during low tide. Species richness, composition, abundance, and diversity indexes such as Shannon-Wiener's diversity index $\left(H^{\prime}\right)$, Simpson's dominance index (D) and Pielou's evenness index (J) were observed. The results showed that there were 19 species found in this study, which belonged to family Stichopodidae, Holothuruidea, and Synaptidae. The highest species richness, abundance, $H^{\prime}$ and $\mathrm{J}$ value was from Tawang coast. Value of $H^{\prime}$ was 2.620 in Tawang, followed by 2.001 in Pidakan, and 1.621 in Labuhan. The highest D index was at Labuhan coast (0.223) compared with Tawang (0.085) and Pidakan (0.158) coast.
\end{abstract}

Keywords: Bangkalan, diversity, Pacitan, sea cucumber, seagrass bed

\section{INTRODUCTION}

Sea cucumber is a group of Holothuroidea in the echinoderm, which are widespread in Indonesian marine waters. They are widely distributed in the sea, such as corals, seagrass beds, rocky, sandy-muddy, and sandy flats habitats (Veronika et al 2015; Wirawati et al 2019). Based on the previous study, there are about 350 types of sea cucumber in Indonesia (Wirawati et al 2019). Sea cucumber or holothurians are slow-moving benthic animals, which can only move along or dig sand with the surface of their tube feet or swim by moving their bodies. They usually play an essential role as keystone species in their ecosystem. Most sea cucumbers are suspension or deposit feeders, which eat a lot of sediment and absorb organic material, which is then excreted (Atkinson et al. 2018). As deposit-feeders, holothurians believed to play a role in the regeneration and mineralization of surface sediments and nutrient cycling (Purcell et al. 2016; Shabana et al. 2018). Furthermore, their digestive process of $\mathrm{CaCO}_{3}$ in the sediment appears to increase alkalinity, which potentially reducing the impact of ocean acidification on coral growth (Setyastuti et al. 2019).

Besides its ecological function, sea cucumber is also used for consumption and medicinal purposes. There are about 56 types of sea cucumber or trepang in Indonesia, which are consumed. Sea cucumber is traded in Indonesia in the form of dried or frozen. Based on data from the Indonesian Institute of Sciences (LIPI), all of them are of the Aspidochirotida order (Holothuroidea) (Setyastuti et al. 2019). Further, sea cucumber has been used as medicine for a long time. Traditional medicine from them is well known as a tonic food that treats damage to the system of the kidneys, reproductive organs, and digestive tract (Setyastuti et al. 2019). Several previous studies have also shown that sea cucumber in Indonesia such as Stichopus hermanni, Thelenota ananas, Thelenota anax, Holothuria fuscogilva, Holothuria leucospilota, Holothuria atra, Holothuria scabra, and Actinopyga mauritiana are the edible species, medical effects, and low toxicity (Pangestuti and Arifin 2018).

Natural resources are not prohibited when it can run in a sustainable manner, and the ecosystem remains in balance. The distribution and diversity of sea cucumber in the intertidal zone are necessary to determine related to their natural habitat, or environmental and anthropogenic factors (Mmbaga 2013; Istiqlal et al. 2018). Intertidal zone at Pacitan and Bangkalan have a potential habitat for Holothuroids, which was covered by seagrass. However, there are still few data on sea cucumber in the area. More 
research is required to better understand the community structure and diversity of sea cucumber at Tawang and Pidakan coasts in Pacitan, and Labuhan coast in Bangkalan with slight differences in habitat characteristics. Therefore, the data from this study could be used as the reference for up-to-date information on sea cucumber diversity as a basis for further management efforts in the region.

\section{MATERIALS AND METHODS}

\section{Study area}

The study sites were located in Tawang and Pidakan coasts in Pacitan, and Labuhan coast in Bangkalan, East Java, Indonesia (Figure1). Field data were collected in the period of June to August 2020.

All the coasts in this study are rocky, but there were e slight differences in characteristics. Tawang is rocky, located in a bay surrounded by hills, so it is relatively protected from waves and strong currents of the Indian ocean. The bottom substrates of Tawang waters were sand, coral fragments, and rocks. There were many tidal pools in the seagrass area, with massive coral colonies. Furthermore, Pidakan is directly facing the open sea (Indian ocean) where it has quite large waves and strong current. Similar to Tawang, there was a rocky beach with coarse sand, coral fragments, and gravel, but the rocks are relatively large. It is quite different from the coasts in Pacitan, Labuhan, located in Bangkalan, on the north coast of Java island facing the Java sea. This rocky coast with a base substrate of gravel, sand, and silt in Labuhan has relatively smaller waves than in Pacitan.

\section{Measurement of environmental variables}

Environmental parameters were measured during low tide. The parameters measured in the field were salinity, temperature $\left({ }^{\circ} \mathrm{C}\right), \mathrm{pH}$, dissolved oxygen content (DO in $\mathrm{ppm})$. Afterward, $500 \mathrm{~g}$ and $100 \mathrm{~g}$ sediment samples were collected at each location with three replications respectively for the substrate types and Total Organic Matter (TOM) analysis.

Collecting salinity data was using an ATAGO® MASTER-S/MillM hand refractometer by dropping a few drops of the seawater sample on the prism (where the sample is placed on the refractometer) under the cover. The salinity scale can be seen through the eyepiece. The temperature and DO of the water surface were measured simultaneously using LUTRON® DO-5510. Then, the acidity $(\mathrm{pH})$ of the waters is measured using an EUTECH® $\mathrm{pH}$ meter.

The substrate type was identified based on the particle size $(2 \mathrm{~mm}, 1.18 \mathrm{~mm}$, and $0.075 \mathrm{~mm}$ ). Average grain size of the sediments was analyzed using the Wenworth (1922) table (Buchanan 1984; Mmbaga 2013) which was then categorized based on the Shepard triangle (Pratiwi et al. 2015). Then the method used in the measurement of TOM was based on SNI 03-2831-1992. Sample analysis was carried out at the Process Engineering Laboratory of the Environmental Engineering Department, Faculty of Civil, Planning and Geo-Engineering (CIVPLAN), Institut Teknologi Sepuluh Nopember (ITS).

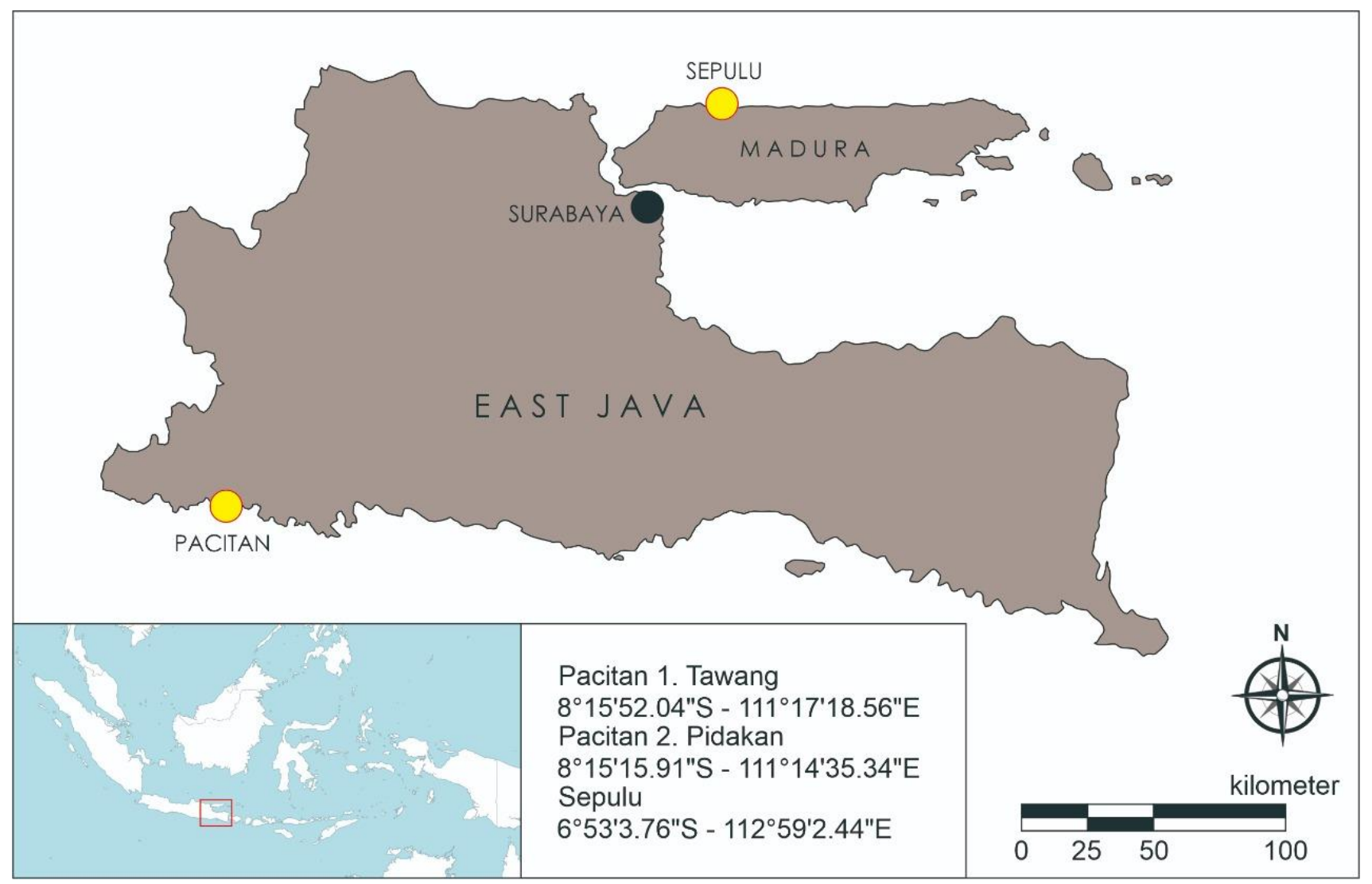

Figure 1. Study area location showing the Tawang and Pidakan coasts at Pacitan; and Sepulu coast at Bangkalan, East Java, Indonesia 


\section{Observation of seagrass coverage}

Seagrass diversity and percentage coverage were carried out using quadratic transects according to English et al (1994). The transect length of $70 \mathrm{~m}$ was placed perpendicular to the shoreline during low tide. The sample squares for analysis of seagrass vegetation were $50 \times 50 \mathrm{~cm}$ and made 6 squares for each transect. Seagrass density was calculated using the following calculation:

$$
D i=\frac{N i}{A}
$$

Where: $D i$ : Density of $i$-th species per $\mathrm{m} 2, N i$ : Abundance in $i$-th species, and $A$ : The total sampling area in $\mathrm{m}^{2}$. The density of seagrass was categorized into three groups: low density $\left(<106\right.$ ind $\left./ \mathrm{m}^{2}\right)$, medium density (between 106-355 ind $/ \mathrm{m}^{2}$ or having an average of 244 ind $\left./ \mathrm{m}^{2}\right)$, and high density (>355 ind $\left./ \mathrm{m}^{2}\right)$ (Odum 1971).

Seagrass cover calculation (English et al. 1994):

$$
C i=\frac{\Sigma(M i x f i)}{\Sigma f}
$$

Where: $C i$ : density of the species- $i$ per $\mathrm{m}^{2} ; M i$ : percentage of midpoint class of the species- $I ; f$ : frequencies (number of grid)

\section{Observation of sea cucumber}

Sea cucumber diversity was observed physically during low tide in a sampling area of around $1000 \mathrm{~m}^{2}$ on each coast. Sea cucumber was recorded once visible and encountered. Sea cucumber specimens that have not been identified in situ are then collected and preserved in 70\% ethanol for further analysis at the Ecology Laboratory and the Laboratory of Zoology and Animal Engineering, Department of Biology, Institut Teknologi Sepuluh Nopember (ITS). Identification to the species level was done following Colin and Arneson (1995), Raghunathan et al. (2013), Setyastuti et al. (2018), and Fatemi and Stohr (2019).

\section{Data analysis}

The data were analyzed by the descriptive-quantitative approach. Species richness represented as the number of species in a particular location and period. While species abundance represented as a number of an individual within the species in the area $\left(1000 \mathrm{~m}^{2}\right)$. Shannon-Wiener index $\left(H^{\prime}\right)$, Simpson's dominance index (D), and Pielou's evenness index $(\mathrm{J})$ were calculated in order to measure the dominance and diversity of species and habitat at each coast (Lampe 2013; Muzaki et al. 2019).

The diversity was calculated using the following calculation:

$$
\begin{aligned}
& H^{\prime}=-\Sigma\left[\left(\frac{n i}{N}\right) \times \ln \left(\frac{n i}{N}\right)\right], D=\Sigma\left(\frac{n i}{N}\right)^{2}, \\
& l=\frac{H^{t}}{\ln (S)}
\end{aligned}
$$

Table 1. Criteria of diversity based on the Shannon-Wiener diversity index (Odum 1971)

\begin{tabular}{ll}
\multicolumn{1}{c}{ Criteria } & \multicolumn{1}{c}{ H' $^{\prime}$} \\
\hline High diversity & $\mathrm{H}^{\prime}>3$ \\
Moderate diversity & $1 \leq \mathrm{H}^{\prime} \leq 3$ \\
Low diversity & $\mathrm{H}^{\prime}<1$ \\
\hline
\end{tabular}

Where: $H^{\prime}$ is the Shannon-Wiener diversity index, $\mathrm{D}$ is the value of Simpson's dominance index, and J is the value of Pielou's evenness index. $\mathrm{Ni}$ is an individual number of the abundance of species- $i, N$ is the total number of individuals in the community, and $S$ is a number of species that occurred in a given area. The criteria for diversity are shown (Table 1). The value of D ranged from 0.00 to 1.00 (Krebs 1999).

\section{RESULTS AND DISCUSSION}

\section{Species richness, composition, and abundance of sea cucumber}

The present study identified a total of three families from the class Holothuroidea. The most dominant family observed was Holothuriidae with fifteen species, followed by Synaptidae and Stichopodidae with three and one species, respectively. Similar results are also reported in South China Sea, Sulu Sea, and Sulawesi Sea (Woo et al. 2013). In Baluran National Park, Indonesia, 16 species were found from Holothuriidae, followed by Synaptidae (2 species), Stichopodidae (2 species), and Chiridotidae (1 species) (Siddiq et al. 2016). Holothuriidae usually dominated in many marine habitats, such as macroalgae, seagrass, coral reef, dead coral, under a rock, and sand (Siddiq et al. 2016).

The highest species richness and abundance were found at the Tawang coast, while the lowest species richness and abundance were from Labuhan and Pidakan coasts (Figure 2). In Tawang, 17 species were found with a total of 50 individuals from the families Holothuriidea, Synaptidae, and Stichopodidae. The highest relative species abundance in Tawang are Holothuria arta and H. impatiens with a value of $14 \%$ (Holothuriidae) followed by Stichopus horrens (10\%) (Stichopodidae), and H. hilla, $H$. leucospilota, and $H$. verrucosa, $8 \%$ each.

Synaptidae was only found in Tawang, and they are characterized by no tube feet, tentacle ampullae, retractor muscles, or cuvierian tubules. They also lack radial canals of the water vascular system, with only the circumoral ring present (Setyastuti et al. 2019). This family was found in Tawang, which had seagrass abundance and coverage for all study sites. The results of previous studies showed that Synaptidae is found in the seagrass and macroalgae, rarely on rocks and dead corals (Siddiq et al. 2016). One of its species, Synapta maculata likes shallow sandy waters and seagrass meadows (Siddiq et al. 2016). 


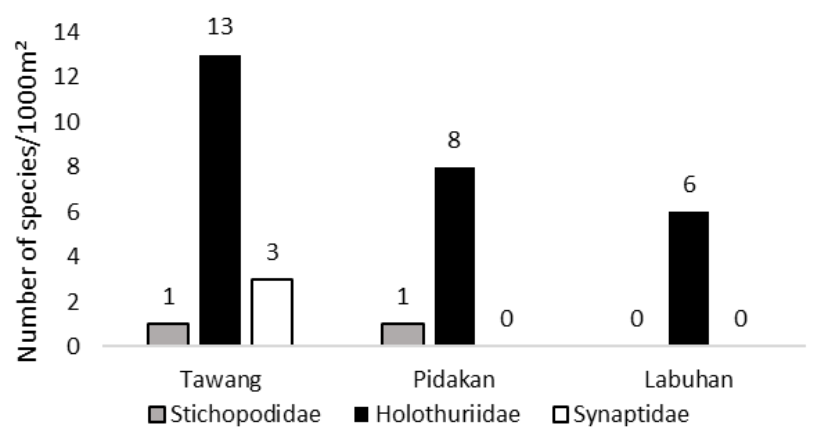

A

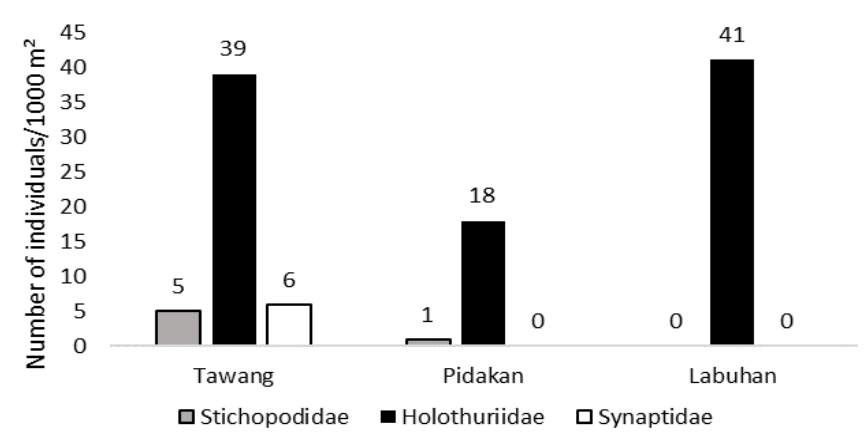

$\mathbf{B}$

Figure 2. Species richness (A) and sea cucumber abundance (B) in Pacitan (Tawang and Pidakan coasts) and Bangkalan (Labuhan coast), East Java, Indonesia

Species richness in Pidakan was lower than the Tawang coast, however, still higher than the Labuhan coast. Nine species were founded from 2 families (Stichopodidae and Holothuriidae) with a total of 19 individuals from Pidakan coast. The most abundant species found were 5 individuals of $H$. cinerascens (Holothuriidae) with a relative abundance of $26.3 \%$ from the total sea cucumber population in the area. Species $H$. excellens, H. hilla, and Holothuria sp. have the same relative abundance which is $15.8 \%$ with 3 individuals each. While other species were found only 1 individual of each species.

At Labuhan coast in Bangkalan, there were only 6 species found in the Holothuriidae family. Based on observations, some species were more dominant than other species, there are H. leucospilota (Holothuriidae) with a relative abundance of $34.1 \%$; followed by $H$. impatiens (22\%), H. excellens (17.1\%), and H. hilla (14.6\%) from the total sea cucumber population in the area.

\section{Species diversity}

Species diversity is usually used to observe the health or ecological stability, which indicates by species richness and individual equality within species (El-Naggar et al. 2017). Based on Simpson's criteria, diversity of sea cucumber in all study sites was in moderate category $(1 \leq$ $\left.H^{\prime} \leq 3\right)$. However, the value of $H^{\prime}$ in Tawang (2.620) was higher compared to Pidakan (2.001) and Labuhan (1.621) coasts. The high $H^{\prime}$ value on Tawang was followed by the lowest Simpson Dominance index value (D), which was the smallest or close to 0 , and indicates little or no species that dominate other species. Tawang coast has a high diversity of sea cucumbers due to the presence of 17 species, and few or no species that dominate other species. Furthermore, the higher value of $H^{\prime}$ usually followed by the higher value of Pielou's evenness index (J) (Muzaki et al. 2019). This study showed that Tawang has the highest $H$ followed by greater $\mathrm{J}$ value (0.925). Likewise, Labuhan has the lowest $H^{\prime}$ followed by the lowest $\mathrm{J}$ value (0.905), which means less evenly distribution of population in that area (Figure 3).

Many factors influence the differences in species diversity of sea cucumber. These include geographic location, habitat type, food availability, sampling time, and sampling methods. The high coverage of seagrass beds in Tawang provides many benefits for sea cucumber life, such as food and shelter sources (Dewi and Prabowo 2015; Setyastuti et al. 2019). On the other hand, the study site in Labuhan was rocky. The lower $H^{\prime}$ value in Labuhan probably was due to less seagrass coverage with less food availability. However, the $H^{\prime}$ value in this study was relatively higher than in the previous study. The results indicate that the range of sea cucumber diversity indices value $\left(H^{\prime}\right)$ in several other locations are $0.146-1.335$ in Baluran National Park (Siddiq et al. 2016); 0.41-0.69 in Bira Island (Komala et al. 2018); 1.0086 in Pombo Island Conservation Area, Central Maluku (Samson et al. 2020).

\section{Environmental variables and seagrass species}

In general, the average value of the physical and chemical variable was still within the range of quality standard that supports marine life, based on the Ministry of Environment of Republic of Indonesia (2004) (Table 2). The substrate types in all study locations were suitable for sea cucumber habitat. They can be found in a variety of habitats. Some species have the habit of burying themselves in the substrate, behind rocks, or in holes. Besides that, there are also several types that choose to be exposed in open areas (Wirawati et al 2019).

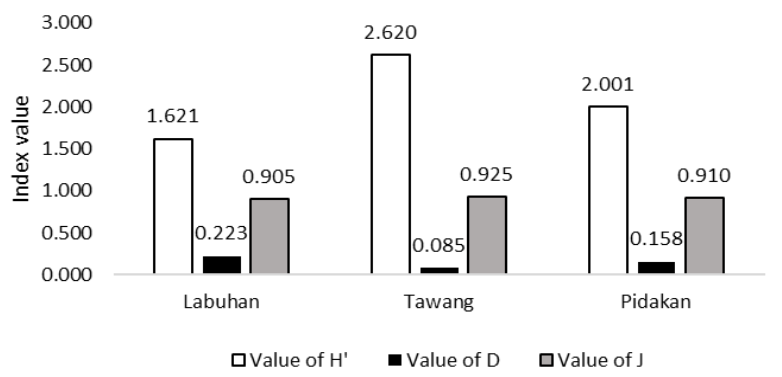

Figure 3. Value of Shannon-Wiener diversity index $\left(H^{\prime}\right)$, Simpson's dominance index (D), and Pielou's evenness index (J) in the study sites 
Table 2. Recorded environmental variables and seagrass species in the study areas

\begin{tabular}{|c|c|c|c|c|}
\hline \multirow{2}{*}{ Parameter } & \multicolumn{2}{|c|}{ Location } & \multirow{2}{*}{ Labuhan } & \multirow{2}{*}{ QS } \\
\hline & Tawang & Pidakan & & \\
\hline Type of substrate & Gravely sand-gravel & Sandy gravel-gravely sand & Gravely sand, silt & NA \\
\hline Total organic matter $(\%)$ & $3.56 \pm 0.60$ & $1.35 \pm 0.370$ & 3.23 & NA \\
\hline Temperature $\left({ }^{0} \mathrm{C}\right)$ & $31.10 \pm 0.173$ & $33.35 \pm 1.047$ & $28.6 \pm 0.420$ & $28-32$ \\
\hline Dissolved oxygen (ppm) & $7.77 \pm 1.626$ & $7.5 \pm 0.868$ & $7.38 \pm 0.130$ & $>5$ \\
\hline $\mathrm{pH}$ & $8.61 \pm 0.093$ & $8.43 \pm 0.156$ & $8.15 \pm 0.16$ & $7-8,5$ \\
\hline Salinity $(\%$ & $32 \pm 1$ & $31.5 \pm 0.577$ & $33.54 \pm 0.36$ & $33-34$ \\
\hline Seagrass species & $\begin{array}{l}\text { Thalassia hemprichii } \\
\text { Halophila ovalis }\end{array}$ & Thalassia hemprichii & Thalassia hemprichii & NA \\
\hline Seagrass density (ind. $m^{2}$ ) & $590.63 \pm 119.476$ & $229.17 \pm 163.705$ & $923 \pm 408.011$ & NA \\
\hline Seagrass cover $(\% /)$ & $66.3 \pm 4.538$ & $28 \pm 22.425$ & $28.21 \pm 17.463$ & NA \\
\hline
\end{tabular}

Note: The average value \pm standard deviation; QS: quality standard based on Appendix III KepMen LH No 51 2004; NA: data not available

Total Organic Matter (TOM) in the sediments in Tawang was found higher $(3.56 \pm 0.60 \%)$ compared to the Pidakan, $(1.35 \pm 0.370 \%)$. While in Labuhan (3.23) had lower TOM than Tawang but higher than Pidakan. Average temperature of water was recorded higher at Pidakan beach (Table 2). The tolerance of sea cucumber to temperature can vary within species and regions. In general, a good temperature for echinoderms to live is $20-30^{\circ} \mathrm{C}$ (Aziz 1998; Simatupang et al. 2017). In tropical waters, some echinoderms can also tolerate temperatures up to $35^{\circ} \mathrm{C}$ (Ubaldo et al. 2007). Based on (Odum 1993), the optimal temperature range for sea cucumber is between $28-31^{\circ} \mathrm{C}$. Temperature conditions outside the optimal range may affect its physiology (Lalli and Parsons 2006).

The average value of dissolved oxygen in all study sites was in the range of quality standard, which is more than 5 ppm. The average $\mathrm{pH}$ was still within a range for the growth and survival of echinoderms. Aziz (1996) and Komala et al. (2018) stated that the optimum pH range for echinoderms is 7.5-8.6. Water salinity was lower than the quality standard. Generally, the intertidal zone has quite high salinity and temperature fluctuations due to the tides of seawater. In general, Echinoderms are stenohaline animals or organisms that can live in a narrow salinity range. However, several species are quite tolerant of changes in salinity (Dewi and Prabowo 2015). Thus, it can be concluded that the environmental parameters of all study sites are still within the normal and ideal range to support marine life including sea cucumbers.

Regarding the seagrass vegetation condition, both coasts in Pacitan were found turtle grass Thalassia hemprichii, which is characterized by a thick rhizome, slightly curved leaves, and 10-40 cm long (Hutomo and Nontji 2014). The density and coverage of T. hemprichii in Tawang $\left(590,63 \pm 119,476\right.$ ind $\left./ \mathrm{m}^{2}, 66,3 \pm 4,538 \%\right)$ was higher compared to Pidakan $\left(229,17 \pm 163,705\right.$ ind $/ \mathrm{m}^{2}$, $28 \pm 22,425 \%$ ). The seagrass at the study site tends to be patchy, but on Tawang beach evenly distributed along the area. There was also found the spoon grass Halophila ovalis, same as previous studies (Dewi and Prabowo 2015; Muzaki et al. 2019). Seagrass at Labuhan also found $T$. hempricii $\left(923 \pm 408.011 \mathrm{ind} / \mathrm{m}^{2}, 28.21 \pm 17.463 \%\right)$.
Seagrass cover is related to the morphological shape and size of the seagrass (Rifai et al. 2013). The same species of seagrass can have different growth forms especially leaves and upright rhizomes. Based on observations, seagrass at Pidakan coast has a smaller size than that found in Tawang. Many factors can affect seagrass growth, including substrate or sediment, waves, and anthropogenic activity. Based on Table 2, the TOM content in Pidakan is lower than that of Tawang, hence the growth of seagrass could be different due to the differences in nutrition for seagrass. Then the sediment texture in Pidakan also consists of relatively larger rocks. This may affect the differences in the seagrass morphology size and its density (Dewi and Prabowo 2015). In Pidakan, presence of strong tidal currents may influence the seagrass growth and reproduction as well as on its survival to be stuck the roots in the bottom of the water. In addition, increasing anthropogenic activities in the form of tourist visits can also potentially disrupt the growth of seagrass in Pidakan (Dewi and Prabowo 2015; Muzaki et al. 2019).

\section{ACKNOWLEDGEMENTS}

We thank Directorate of Research and Community Service (DPRM) and Biology Department of Institut Teknologi Sepuluh November, Surabaya, Indonesia for the local grant schemed as Penelitian Dana Departemen 2020. We thank also to the locals in Pidakan, Tawang, and Labuhan for supporting the research.

\section{REFERENCES}

Atkinson L, Mah C, Filander Z. 2018. Phylum Echinodermata. In: Atkinson LJ, Sink, KJ (eds). Field Guide to the Offshore Marine Invertebrates of South Africa. Malachite Marketing and Media, Pretoria.

Aziz A. 1996. Habitat and zonation of echinoderm fauna in coral reef ecosystem. Oseana 21 (2): 33-43. [Indonesian]

Aziz DR. 1998. The effect of thermal stress on Echinoderm fauna (Pengaruh tekanan panas terhadap fauna Ekhinodermata). Oseana 8(3): 125-132. [Indonesian] 
Buchanan JB. 1984. "Sediment analysis". In: Holme NA, Mcintyre AD. (eds). Methods of study of marine benthos, 2nd edition. Blackwell Scientific Publications, Oxford.

Colin PL, Arneson C. 1995. Tropical Pacific Invertebrates: A Field Guide to the Marine Invertebrates Occurring in Tropical Pacific Coral Reefs, Seagrass Beds and Mangroves. Coral Reef Press, California.

Dewi NK, Prabowo SA. 2015. The status of seagrass beds in tourism beaches of Pacitan (Status padang lamun pantai-pantai wisata di Pacitan). Biogenesis: J Ilm Bio 3 (1): 53-59. DOI 10.24252/bio.v3i1.567. [Indonesian]

El-Naggar HA, El-Gayar EE, Mohamed ENE, Mona MH. 2017. Intertidal macro-benthos diversity and their relation with tourism activities at Blue Hole Diving Site, Dahab, South Sinai, Egypt. Sylwan 161 (11): 227-251. DOI: 10.13140/RG.2.2.17950.84804.

English S, Wilkinson C, Baker V. 1994. Survey manual for tropical marine research. ASEAN-Australia Marine Science Project. Australian Institute of Marine Science, Townsville, QLD.

Fatemi Y, Stöhr S. 2019. Annotated species list of Ophiuroidea (Echinodermata) from the Persian Gulf and Gulf of Oman, with new records. Zootaxa 4711 (1): 77-106. DOI: 10.11646/zootaxa.4711.1.3.

Hutomo M, Nontji A. 2014. Manual for Moniroting of Seagrass Bed (Panduan Monitoring Padang Lamun). COREMAP CTI LIPI, Jakarta. [Indonesian]

Istiqlal BA, Kasa IW, Yusup DS. 2018. Invertebrates diversity of Merta Segara and Nyangnyang beach: Comparison study of two beaches with different characteristics. Adv Trop Biodv Env Sci 2(2): 14-20. DOI: 10.24843/ATBES.2018.v02.i02.p01.

Komala R, Miarsyah M, Wulaningsih RD. 2018. Echinoderms of the coral reef ecosystem and their utilisation at Bira Island of the Seribu Islands; The 9th International Conference on Global Resource Conservation (ICGRC) and AJI from Ritsumeikan University. A Join Conference of Brawijaya University and Ritsumeikan University, Malang, 7-8 March 2018. [Indonesian].

Krebs CJ. 1999. Ecological Methodology. $2^{\text {nd }}$ ed. Benjamin Cummings, Menlo Park, CA.

Lalli CM, Parsons TR. 2006. Biological Oceanography: An Introduction Elsevier, China.

Lampe K. 2013. Holothurian density, distribution and diversity comparing sites with different degrees of exploitation in the shallow lagoons of Mauritius. SPC Beche-de-mer Inf Bull 33: 23-29. DOI 10.14203/oldi.2016.v1i3.7.

Ministry of Environment of Republic of Indonesia.2004. Resolution no 51 year 2004, Appendix III.

Mmbaga TK 2013. The effect of fishing on the ecology of sea cucumber (Holothuroidea: Echinodermata) Holothuria scabra and Holothuria nobilis in Tanzanian seawater. Intl J Sust Dev 2(2): 1099-1126.

Muzaki FK, Setiawan E, Insany GFA, Dewi NK, Subagio IB. 2019 Community structure of Echinoderms in seagrass beds of Pacitan beaches, East Java, Indonesia. Biodiversitas 20(7): 1787-1793. DOI 10.13057/biodiv/d200701.

Odum EP. 1971. Fundamentals of Ecology. 3rd ed. W.B. Saunders Co., Toronto.

Pangestuti R, Arifin Z. 2018. Medicinal and health benefit effects of functional sea cucumbers. J Trad Comp Med 8(3): 341-351. DOI: 10.1016/j.jtcme.2017.06.007.
Pratiwi MJ, Muslim M, Suseno H. 2015. Study on sediment dispersal based on textures in Sayung waters, Demak. J Ocean 4 (3): 608-613. [Indonesian]

Purcell SW, Conand C, Uthicke S, Byrne M. 2016. Ecological roles of exploited sea cucumbers. Ocean Mar Biol 54: 375-394. DOI: $10.1201 / 9781315368597-8$

Raghunathan C, Sadhukhan K, Mondal T, Sivaperuman C, Venkataraman K. 2013. A Guide to Common Echinoderms of Andaman and Nicobar Island. The Director, Zool Surv India, Kolkata.

Rifai H, Patty SI, Simon L. 2013. Community structure of seagrass bed in Mantehage island, North Sulawesi (Struktur komunitas padang lamun di perairan Pulau Mantehage, Sulawesi Utara). J Ilm Platax 1(4): 177186. DOI: 10.35800/jip.1.4.2013.3699. [Indonesian]

Samson E, Wakano D, Rahanawatty H. 2020. Community structure of Sea Cucumber (Holothuroidea) in Pombo Island Conservation Area, Central Maluku. J Phys Conf Ser 1463(1): 012027. DOI: 10.1088/1742-6596/1463/1/012027.

Setyastuti A, Purbiantoro W, Hadiyanto H. 2018. Spatial distribution of echinoderms in littoral area of Ambon Island, Eastern Indonesia. Biodiversitas 19 (5): 1919-1925. DOI: 10.13057/biodiv/d190544.

Setyastuti A, Wirawati I, Permadi S, Vinomo IB. 2019. Indonesian Sea Cucumber (Teripang Indonesia). Media Sains Nasional, Jakarta. [Indonesian]

Shabana EE, El Kazzaz WM, Dar MR, Dewedar A. 2018. The influence of Holothuria atra (Echinodermata: Holothuroidea) on organic matter assimilation, ammonification and nitrification rate of sediment Hurghada, Red Sea, Egypt. J Sci Rsch Sci 35 (part 1): 1-15. DOI: 10.21608/jsrs.2018.25515.

Siddiq AM, Atmowidi T, Qayim I. 2016. The diversity and distribution of Holothuroidea in shallow waters of Baluran National Park, Indonesia. Biodiversitas 17 (1): 55-60. DOI: 10.13057/biodiv/d170108.

Simatupang MYC, Sarong MA, Ulfah M. 2017. Diversity of Echinoderm and environmental condition of shallow water in Pandang Island, Batu Bara Regency, North Sumatra (Keanekaragaman Echinodermata dan kondisi lingkungan perairan dangkal Pulau Pandang Kabupaten Batu Bara Provinsi Sumatera Utara). J Ilm Mhs Kelautan Perikanan Unsyiah 2(1):97-103. [Indonesian]

Ubaldo JP, Uy FA, Dy DT. 2007. Temperature tolerance of some species of Philippine intertidal echinoderms. Philippine Sci 44: 105-119. DOI: $10.3860 /$ psci.v44i0.381.

Veronika K, Edrisinghe U, Sivashanthini K, Athauda ARSB. 2015. Abundance and diversity of sea cucumbers in point Pedro coastal waters in Jaffna peninsula of Sri Lanka. Trop Agric Rsch 27(2): 182189. DOI: $10.4038 / \operatorname{tar} . v 27 i 2.8166$.

Wenworth CK. 1922. A scale of grade and class terms for clastic sediments. J Geology 30: 377-392. DOI: 10.1086/622910.

Wirawati I, Setyastuti A, Purwati P. 2019. Sea Cucumbers of Indonesian Shallow Water (Timun Laut dari Perairan Dangkal Indonesia). Med Sains Nasional, Jakarta. [Indonesian]

Woo SP, Yasin Z, Ismail SH and Tan SH. 2013. The distribution and diversity of sea cucumbers in the coral reefs of the South China Sea, Sulu Sea and Sulawesi Sea. Deep-Sea Res Part II Top Stud Oceanogr 96: 13-18. DOI: 10.1016/j.dsr2.2013.04.020 